JELTL (Journal of English Language Teaching and Linguistics) e-ISSN: 2502-6062, p-ISSN: 2503-1848

2020, Vol. 5(3)

www.jeltl.org

\title{
Pragmatic Analysis of Flouting Maxim in Donald Trump's Interview with TIME in the Oval Office 2020
}

\author{
Isma Farikha Latifatun Nuzulia \\ Universitas Brawijaya \\ ismafarikha@gmail.com
}

\begin{abstract}
The purpose of this research is to define a linguistic feature based on Donald Trump's interview with TIME since Trump is a politician who has the power to influence others, and it can be extremely essential to analyze how the hidden meaning in his utterance images him as a public figure. This research uses the descriptive qualitative method because the object of the study is a transcript containing utterance and conversation. Grice's (1975) theory is used in this study to define the flouting maxim that occurs during the interview. The result of this study is that 11 utterances containing flouting maxim of quantity, 3 flouting the maxim of relation, 2 flouting the maxim of manner, and no flouting maxim of quality is found in this study. After analyzing the finding, the most dominant found types is flouting maxim of quantity which means that Trump frequently gives more information than required to express his interest and to show his power as a president and his nationalism as representative of American.
\end{abstract}

Keyword: Flouting maxim, Utterance, Politic

\section{INTRODUCTION}

Language plays a significant role in our life to communicate or to deliver the idea with others that can be categorized as a written or spoken language. Spoken language likes conversation, speech, debate, or utterance which involves a speaker and a hearer to give simply response. Furthermore, language can be successfully understood by the speaker and audience when the roles of communication are completed. Then, to achieve success in the communication it clearly required an accepted rule which can be analyzed in linguistic features as flouting maxim in pragmatic aspect. Additionally, if a conversation did not 


\section{Isma Farikha Latifatun Nuzulia}

complete the rule of the cooperative principle, it will constitute a flouting of a pragmatic feature called the flouting of the maxim. Yule gives a further explanation about pragmatics that "pragmatics is concerned with the study of meaning as communicated by a speaker (or writer) and interpreted by a hearer (or reader)" (Yule: 1996, p 9). From this explanation, the conversation has deep meaning regardless for speaker or hearer and it can be analyzed by pragmatic features to obtain an accurate result. Also, Grundy (2000) also states that the study of pragmatic also about contexts in which have indirect meaning the utterance.

Moreover, flouting maxim occurs when communication does not effectively deliver which is easily found in human's daily life such as conversation, asking a question, and answering it. In pragmatics, to ensure effective communication, it should formulate accepted rules which are purposed to avoid misunderstanding. Additionally, human talking aims to achieve cooperative effort creating with good comprehension. It means that comprehension is definitely needed for the speaker toward the utterances to be delivered to the hearer. In addition, to gain comprehension, it requires cooperative principle introduced by Grice (1975) such as the maxim of quantity, quality, relation, and manner. Griffith (2006, p.134) states that maxim 'is a pithy piece of widely-applicable advice' that means to gain effective communication, speakers require to guide the maxim. To apply the cooperative principle, the speakers should apply maxims in their utterances. When the speakers disobey the rules of the maxim and the hearers try to appreciate the implied meaning which is not directly shown in utterances, it would create a situation of disobeying of cooperative principle called the flouting of the maxim (Cutting: 2002).

Flouting maxim occurs when speakers disobey the rule of the cooperative principle and the hearers may lead to misunderstanding what the speakers say. Also, the hearers will think the meaning which is not directly expressed. According to Hall and Hall (1990), highcontext people can be impatient and irritated when receiving the information, they do not require, however, low-context people also become at a loss when they obtaining insufficient information. From this explanation, it can contribute the adverse effect of flouting maxim toward the hearer regardless of high or low-context people. Then, there are various ways people avoid the flouting of maxim such as giving a sufficient amount of information, avoid to tell an untruth, made the relevant question, making clear text, and message (Leech: 1983). Thus, the hearer should find the implicature in the utterance as Grice (as cited by Brown and Yule:1983) that implicature is a meaning to be implied, advised, or meant, that is explicitly mentioned in the utterance.

Furthermore, an interview is one of the ways people communicate or express their feeling that involves two ways of communication, and in human's daily life, it is used to deliver the meaning in the political aspect which could form public opinion in mainstream society. Chilton and Schaffiner (1997, p.206 as cited by Dunmire) explain that it is surely the case that politics cannot be conducted without language, and it is probably the case that the use of language in the constitution of the social group leads to what we call politic in aboard sense.' From this, the study of the political phenomenon has strong interaction with language not only about the relationship itself but also the meaning of the utterance. Additionally, politics could be analyzed by linguistic features especially the pragmatic of flouting maxim by Grice (1975) that will be investigated in this research. 
To elaborate on this study, it is extremely essential to analyze using pragmatic features of flouting maxim in the case of the interview because this way can show the hidden meaning in the utterance conveyed by the politician. Also, the political background can control and influence mainstream society's behavior and value. Similarly, this explanation is stated by Edelman (1977) that the politician's statement and action can assist to generate public opinion toward them. Additionally, it is highly important to know the meaning of every politician's utterance to gain the implicature which is not showing directly in the utterance. Similarly, it is stated by Levinson (1983) the study of implicature is to find several explicit accounts that feasible to not speak or it more than something strictly speaks. The object of this study is a transcript conversation of an interview between TIME, and Donald Trump that is obtained from the website namely time.com. This website provides various information on Americans such as politics, business, health, tech, entertainment, science, sport, and others. The reason for choosing the flouting maxim to be analyzed is because this kind of communication can investigate the meaning of the utterance which is spoken by the speaker not only in the terminology but also in the deep meaning related especially for hidden meaning uttered. Besides, it also can demonstrate how political figures deliver their meaning showed in their utterance. According to Wareing (2004, p.9), the function of language is highly essential for those who are allowed to speak the speech that is 'deeply tied up with power and social status.' This language plays an important role for people to show their social status, in this case is politicians to show their power and status toward contemporary society.

Several previous studies conducted have differences and similarities with this recent research. Firstly, in the study entitled 'The Cooperative Principle in Political Discourse: Flouting Gricean Maxim in Modern Standard Arabic Political Speech' by Al-Qaedri (2019) and Alduais, the similarities found that this previous study is used political background as the subject of the study and the same theory by Grice (1975). However, the difference in the result of the study, this previous research concludes how to evaluate Grice's theory toward the final finding, however, this current study completes analyzing the political background that plays a rule to flout a maxim conveying the hidden meaning. It is extremely essential to analyze the political background as the expert states that language has a strong power of expression in the rhetoric studying that could strongly affect the audiences. (Partington and Taylor, 2010).

Furthermore, 'An Analysis of Flouting of Maxim Performed by Politician Guest in Mata Najwa Talkshow in the Episode of Adu Lantang Jelang Penetuan dan Babak Akhir Pilpers' by Aisya and Fitrawati (2019), and an article entitled 'But We're Talking About Half-Beast Human: Conversational Implicature in the Television Talk Show with Anwar Ibrahim' by Larasati (2016) shows similarity toward the political background as the object of the study and Grice (1975) as the main theory. There is a small difference between both previous studies and this current study that in the former states the reason for politicians fluted a maxim is because to hold power and responsibility and the latter explain the causes of flouting a maxim is to show sympathy and emotional bound. However, this current study summarizes the different conclusions of the reason of politician flouted a maxim and complete the other theory of political language by other experts to create more credible of the research. This current study will complete concluding how the power of politicians as a 


\section{Isma Farikha Latifatun Nuzulia}

public figure that is expressed in their utterance. Thus, the utterance provided is to find the hidden meaning as Fairclough (1989, p.40) said that 'but class relations and positions are not directly expressed and reproduced in most practice'.

\subsection{Research Question}

1. What are the flouting maxims found in the interview of Donald Trump with TIME in the Oval Office?

2. What is the most dominant found of type of flouting maxim in the interview of Donald Trump?

\section{LITERATURE REVIEW}

\subsection{Pragmatics}

According to Yule (2010), pragmatic is the study to recognize the hidden meaning in which it is not directly written or spoken. They use the term 'invisible' to discuss the meaning which cannot be understood when only read the utterance. To obtain adequate information about the hidden meaning, it is required insight to make an assumption and expectation. Additionally, the scope of pragmatic is about to conduct the meaning, which could be obtained in the communication of human beings, between speaker and hearer. Then, Mey (2001, p.6) explains that 'pragmatics studies the use of language by human as determined by the condition of society'. Accordingly, the study of pragmatic is also related to the condition of society as a result of the development of meaning in the utterances.

Spencer-Oatey and Zegarac (2010, p.72) states that "pragmatic is concerned with the study of the meaning that linguistic expression receives in use'. From this explanation, it means that pragmatic have significant relation with linguistic that can be conducted the meaning involved. It is called that pragmatic and linguistic is connected since linguistic can express various meaning which is strictly showed. Similarly, Grundy (2000, p.13 as cited by Chojimah) explains that pragmatics has close relation with context "context can help readers or listeners to determine the meaning of what is said.' According to this, pragmatic is a study about the meaning which can be investigated toward the context in the communication. Kroeger (2018) also gives explanation about pragmatic that is a study in which concerned with aspect of meaning that is used in the sentence and words. According to this, pragmatic scope has strong connection with the meaning which is used by humans beings in communication, and these sentence or utterance can be analyzed in various aspects to find out the meaning.

\subsection{Cooperative Principle}

Grice (1975) state to achieve the co-operative principle in communication, he categorized four rules that must be obeyed by the speaker and hearer.

The maxim of Quantity. To establish the maxim of quantity Cutting (2002, p.34) states that 'speakers should be as informative as it required, that they should give neither too little information nor too much.' From this, it is highly important to give sufficient informative as needed, not giving too much or too little since it is purposed to create good communication. 
Similarly, Cruse (2000, p.376) explains 'the maxim of quantity is concerned with the amount of information (take in its broadest) sense an utterance convey.' He discusses that the number of information sharing by the others can be indicated as maxim of quantity whether it is giving sufficient data or no. However, this type of co-operative principle is purposed not to be over-informative since it can waste the time and make the hearer confusing, and finally it will be feasible for the hearer to receive misleading information.

The Maxim of Quality. The rule of maxim quality that should be obeyed by the speakers to achieve effective communication is 'Do not say what you believe to be false' and 'Do not say that for which you Sperber and Wilson, lack adequate evidence.' (Grice 1975, p.46). Grice (1975,p.46) states 'try to make your contribution one that is true'. This explanation discusses how important to give true information to obey the rule of this cooperative and avoid spread misleading information when understanding this information is false and lack of evidences. Cruse (2000, p.355) uses the phrase 'do not make unsupported statement' to explain the rule of maxim quality that means to not give inadequate evidence or false information when sharing the information to others.

Maxim of Relation. Grice (1976) uses a single maxim to explain the rule of these types that to give relevant answers or information we should pay attention to the relation in the topic involved, this is 'be relevant.' Also, maxim relation is 'the speaker assumed to be saying something that is relevant to what has been said before' (Cutting, 2002, p.35). For example, when others ask a question about something, we should answer related topics with that, not exchange for a different topic.

The Maxim of Manner. The last category of maxim has several role as Cutting (2002, p.35) explanation 'we should be brief and orderly, and avoid obscurity and ambiguity.' Here, the speaker should avoid the behavior that can make the hearer confused such as obscurity and ambiguity in the conversation or utterance. Grice (1975) says this maxim with the term of 'supermaxim' since there are many roles that should be obey. Grice (1976) explains it is like to avoid obscurity of expression, ambiguity, convey detailed information, and to be orderly when providing data.

\subsection{Flouting Maxim}

According to Thomas (1995, p.65) 'a flout occurs when a speaker blatantly fails to observe a maxim at the level of what is said, with the deliberate intention of generating an implicature.' From this, flouting maxim is a situation that a rule of the co-operative principle, which is the maxim of quantity, quality, relation, and manner are not completed, the speaker disobeys the rule of the cooperative principle that the hearers should find an implicature or hidden meaning which is not directly spoken.

Flouting the Quantity Maxim. Cutting (2002, p.37) explains 'the speaker who flout the maxim of quantity seems to give little or more information.' According to this, flouting maxim of quantity occurs when the speaker shares more information which is not required or gives limit the data.

Fluting the Quality Maxim. Grice (1975) gives an example of the maxim of quality in several categories, they are irony, metaphor, meiosis and hyperbole, all of which is indicated as flouting maxim of quality since the speakers share untruth information or the give the data which is lack of evidences. According to Griffith (2006) irony is an utterance to be 


\section{Isma Farikha Latifatun Nuzulia}

conveyed but it has opposite meaning from the literal meaning. The usage of irony is like antonymy which means a term having contradictive meaning. Then, Metaphor a metaphor occurs when the speaker comparing between two contradictive something in the same phrase. Griffith (2006, p.78) states that 'metaphor tend to provoke thought and feeling to a greater extent than more literal description do'. This means that by doing metaphor, speaker is indicated to give untruth information. Besides, Meiosis is expressing something uses indirect sentences. Here, Grice (1975, p.53) gives the example of when people broke the furniture, the other says 'he was a little intoxicated.' This term is purposed to explain the reason for people to do with the furniture. Also, hyperbole based on Oxford Dictionary hyperbole is 'a way of speaking or writing that makes something sound better, more exciting, more dangerous and others'. From this explanation, when people use hyperbole in their utterance, they try to deliver something that is not the fact.

Flouting the Maxim Relation. This type of maxim occurs if the speaker contributes to give the information which is irrelevant to the question. Here, Grice gives an example when at a party A says ' $M r . X$ is an old bag' then, B says 'The weather has been quite delightful this summer, hasn't'? (Grice, 1975,p.53). This example shows that the answer of B does not relate to the question and it is called a flouting the maxim relation. Similarly, Cutting (2002, p.39) says when the speakers flout a maxim relation 'they expect that the hearer will be able to imagine what the utterance did not say, and make the connection between their utterance and preceding one(s).' According to this, the hearer should find the hidden meaning in the speaker's utterance that is create difficult to convey the idea.

Flouting the Maxim Manner. This category of maxim occurs if 'the writers play with words to heighten the ambiguity, in order to make a point' (Whitehorn as cited by Griffith 2006). The speakers do not give a brief answer or giving perspicuous information however, they give data that difficult to be understood and maybe obscure, disorderly, and ambiguous. Cruse (2006) something can be identified as an ambiguity if it expresses more one possible meaning.

\subsection{Implicature}

According to Horn (2000, p.3) implicature is a component of speaker meaning that constitutes an aspect of what is meant in the speaker's utterance without being part of what is said.' From this, implicature is a study of communication to understand the meaning which not literally expressed. Besides, the hearer should try to understand the hidden meaning in the utterance. Yule (2010) illustrates with an example of implicature in the conversation that Carol asks a question 'Are you coming to the party tonight?' and Lara answers 'I've got an exam tomorrow." (2010,p.148). From this example, Lara does not give a direct answer whether yes or no to going to the party tonight, but she answers that she will take an examto-day letter. By Lara's explanation, Carol may understand that Lara cannot come to the party since she should prepare for the exam tonight. It is called implicature which means indirect communication. 


\section{RESEARCH METHODS}

This research used a descriptive qualitative method as a research design since this study is purposed to analyze how flouting maxim occurs in the interview of Donald Trump with Time. Similarly, Creswell (1997) explains that qualitative research conducts a process toward social or human complication. Additionally, Grice theory (1975) is used as the primary theory to support this research. Furthermore, the research subject of this study is utterance containing a flouting maxim introduced by Grice (1975). Since this research subject is involved in two-way communication between Trump and the interview, it will be easy to find the utterance which contains flouting maxim in Trump's answer toward the question. Then, a data source to obtain data is the website namely time.com, and from this online website, the researcher directly obtains the transcript during the interview.

To collect the data, the first step is to search the transcript interview of Donald Trump on the online website of time.com then, downloading this transcript to investigate further stages. Next, reading the script which contains flouting maxim in every paragraph, then selecting the utterances consisting of four types of flouting maxim to be analyzed. Initially, analyzing the data is identifying the flouting maxim which is found in the previous step. Then, classifying four distinctive categories of fluting maxim to analyze the data, after that analyzing the highest quantity of flouting maxim found. Eventually, drawing the conclusion based on finding regardless of all number types found and draw the biggest quantity.

\section{FINDINGS}

In this study, the researcher found 16 utterances containing flouting maxim which means the speaker does not obey the rule of the cooperative principle. Besides, three types of flouting maxim are found in the transcript, all of which flouting maxims maxim of quantity, relation, and manner. However, a flouting maxim of quality does not find during the analysis.

\subsection{Flouting Maxim of Quantity}

The flouting maxim found in the transcript was 11 out of 16 data and this quantity is observed as the most dominant category than the others type. This type frequently occurs since Trump usually conveys more information than needed, and it is like providing an example of other country cases, illustrating the good relationship between the USA and other notions, and explaining the significant role of America to the world.

TIME: How much of the challenge?

TRUMP: [to an aide] I'm talking about through the Straits. The oil that comes in by country. I had it yesterday. Who would have it? Maybe Bolton would have it, or somebody

Which is a pretty shocking thing. You look at China, it's a big beneficiary - they don't pay anything. Japan is a big beneficiary, they don't pay anything. Many other countries, they don't pay anything. Indonesia. Many other countries come, they don't pay anything. And we're there keeping the world as, you know, we're there keeping the oil flowing. Right? And the amazing thing is we're now an exporter, so in theory, we're a beneficiary of oil 


\section{Isma Farikha Latifatun Nuzulia}

The example above is an utterance containing the flouting maxim of quantity because Trump gives more information required to be answered. The interviewer asks a question about how hard the challenge for producing oil which is previously discussed, but Trump does not directly give a clear answer. He explains that many counties in the world such as China, Japan, and Indonesia, do not provide sufficient aid for keeping the world however, America still maintains the world and becomes a great country exporting oil. Furthermore, in the last sentence, Trump explains that the problem is to become beneficiary oil that means there is nothing serious problem of producing oil in America, and this answer is the acceptable answer from the question given by the interviewer. On the other hand, the explanation about the countries mentioned is not required, and it provides more additional information which can be difficult to find the real answer.

The other example of flouting maxim occurs when the interview wants to know Trump's message toward the Hong Kong demonstration, which holds as the big demonstration last year, but Trump also shares much information about the relationship toward China.

TIME: So just continuing on this idea of America's role on the world stage, what is your message to the demonstrators in Hong Kong right now?

TRUMP: Well, look, my message is that they're obviously having a big impact, because it's been pulled back and it will be pulled back further. And I think that they've been very effective in their dealings with China. By the way, I have a very good relationship with China, just that they've treated us unfairly with respect to trade for many years. Since the WTO, we've been treated unfairly. We've helped create China. I give them a lot of credit, but we've helped create China. You look at what's happened over the last period of time, and China wants to make a deal. They actually had a deal with us. We were very close to having a deal, and then they pulled back on three major points that were just unacceptable to me. So I'm very happy now collecting $25 \%$ on $\$ 250$ billion, which is what we're doing. But China wants to make a deal, and I don't blame them, because companies are leaving China by the hundreds because they don't want to pay the tariffs. So China's going to want to make a deal.

From this, the message of Trump for demonstration in Hong Kong, they have a significant role in agreeing with China which is expressed at the beginning of the sentence. However, Trump gives further information to provide additional data which is starting with the phrase 'by the way.' Trump explains that he as a representative of American has a good relationship with China, but China is unfair when cooperate with America. Then, Americans assist China by providing credit but in the end, they are left by the manufactures because of cheating they make. Furthermore, the other example of flouting the maxim of quantity is that Trump explains more about reinstating family to policy using the other case of the president.

TIME: Would you consider reinstating the family separation policy?

TRUMP: So let me tell you about that. It's very interesting. President Obama had separation. I'm the one that brought it together. I was the one, and what that did is it made more people come up because I didn't like separation any more than you did. 
But if you look at those cells, where they were showing all these cells, they looked like jail cells or cyclone fence - but they look like jail cells. They were built in 2014 by Obama. I think you people had one of those pictures actually. You said look at these cells. It turned out they were built by Obama. They were built by people that I know very well. People that want to come into the Administration. But if you look at the separation policy, I had that policy, and then I'm the one that put the families back together. When you put the families back together, you have more families come up. It's a very simple...

From this illustration, Trump should answer whether he wants to reinstate the family separation policy or no, this way is purposed to obtain a relation answer to the question. However, he illustrates the Obama separation case in his answer to support his argument, and he also explains the role of him in the administration.

\subsection{Flouting Maxim of Relation}

There are 3 data containing flouting maxim of relation in the transcript of interview. This category occurs since Trump gives unrelated respond toward the question asked.

TIME: What would you do if a foreign power launched a propaganda effort to halt a Democratic opponent?

TRUMP: Well, I've said, you know what? I've answered it so many different ways I answered it in Stephanopoulos, I answered the same question on Fox. But number one, I don't think they'd do it with me because they know I love the country -

Here, the interviewer asks a question about what Trump will do if propaganda launched by the foreigner to assist the democratic opponent, however, to represent a response, Trump give irrelevant information with the back question in the beginning after which, he says that he answers the others question in different ways. Also, he thinks that the democrats do not do this because they know that Trump has nationalism toward his notion. To obey the cooperative principle, Trump should give an explanation of what he will do if the action happens.

The other case of flouting the maxim of relation occurs when Trump also discusses different topic toward the question asked. In this section, the interview asks a question about how Trump delivers his promise to mainstream society.

TIME: So how do you deliver on the promise?

TRUMP: Even look at the First Quarter, we're at 3.2\%. Nobody expected that. They thought it would be one - you know, the First Quarter is always very low. We're at $3.2 \%$. The economy is so strong that people are coming up. Now what I did with Mexico is, Mexico - I don't know if you've seen, but the numbers are way down since they started last week, and they haven't even - they're putting their - they're starting to move the 6,000 soldiers in tomorrow.

And I think they're working very hard.

Trump gives information that is unrelated to the topic of the question and he answers using the data exactly which consists of several economic power. Also, Trump explains that 


\section{Isma Farikha Latifatun Nuzulia}

the more people coming the more opportunity to be stronger. Furthermore, the other example of a flouting maxim of manner occurs when Trump draws his response toward the supporters who voted for him.

TIME: Do you sense that your supporters who voted for you and heard about how you're going to crack down on immigration and reduce illegal flows are disappointed?

TRUMP: Look, I'm building a wall despite the fact that the Democrats don't want a wall built. They have fought every - we just won a lawsuit on the wall. I don't know if you saw that, a big one, a very important one, against Nancy Pelosi in the House. They sued us, and we won a lawsuit last week, a very big one. We're building a wall, the wall is going up as we speak. We've already renovated vast amounts of wall, taking inferior product and making it very good, very strong. We had walls, we built walls in San Diego.

Based on this datum, Trump should express his opinion toward the supporter who voted for him is disappointed or no. On the other hand, Trump does not give a direct answer but explains the wall he built which is democrat do not want to build it. Here, Trump states that building plays a significant role to speak, and he also has renovated it very quickly to make it absolutely good. Additionally, this utterance is indicated as a flouting maxim of relation that Trump did not obey the cooperative principle to 'be relevant.'

\subsection{Flouting Maxim of Manner}

There are 2 data indicating as flouting maxim of manner occurs in the interview of Trump. This type happens because Trump gives an ambiguity and unclear information.

TIME: Are they calling your bluff on this or how do you see it?

TRUMP: Time will tell. Only time will tell.

According to the datum, clear information is required such as yes or no toward they (Iran) calling Trump and explain the opinion of Trump to respond the case, but Trump answer that the only thing to answer the question is time. Additionally, the information providing by Trump indicates that Iran did not call Trump recently, however, he uses the phrase which can make the hearer should think more to understand the meaning.

The other example of a flouting maxim of manner occurs because Trump does not give information but repeatedly asks the same question.

TIME: Do you bet? I have forgotten whether you bet or not?

TRUMP: Do I bet?

Based on the datum, the interview starts the question using 'do' which means it needs the question yes or not, however, Trump asks the same question. This case can make an ambiguity and do not obey the cooperative principle. 


\subsection{Frequency the Category of Flouting Maxim Found}

Table 1: Frequency of types flouting maxim

\begin{tabular}{lcc}
\hline Types of Flouting Maxim & Frequency & Percentage \\
\hline Flouting Maxim of Quantity & 11 & $68.75 \%$ \\
Flouting Maxim of Relation & 3 & $18.75 \%$ \\
Flouting Maxim of Manner & 2 & $12.5 \%$ \\
Flouting Maxim of Quality & 0 & 0 \\
\hline Amount & 16 & $100 \%$
\end{tabular}

According to the table, the most dominant found flouting maxim is the maxim of the quantity which is represented at precisely $68.75 \%$, and in this case, it means that Trump frequently gives more information than required. Besides, the maxim of the relation is observed as the lowest contribution at exactly $18.75 \%$, and $11.7 \%$ successively. Additionally, Trump sometimes fluted maxim relation that means he gives an unrelated answer which different from the topic question. Moreover, Trump also gives unclear information which is indicated as a flouting maxim of manner that makes the hearer should think more about what the speaker want. Eventually, the maxim of quantity is not found in the transcript that means Trump is extremely rare to use phrases indicated maxim of quality such as irony, metaphor, meiosis, and hyperbole.

\section{DISCUSSION}

After analyzing the data, it is reported that the largest number category of flouting maxim is maxim quantity at just above half of all the percentage. According to Cutting (2002) to establish the cooperative principle of maxim quantity the speaker should provide sufficient information as required, avoid being over-informative, and avoid giving too much or too little data. On the other hand, in the data, Trump frequently gives more information than required such as provide information about the role of him as a representative of American to assist other countries, comparing American's roles than other countries, explaining the good relationship between America and other notions, and others. All of this information is more than required from the question asked. When Trump flouting the maxim of quantity, it is indicated that he is interested in the topic received. To illustrate this case, in the utterance containing flouting maxim of quantity, Trump explains more when the interviewer asks about considering to reinstate the family separation policy. Here, Trump explains in a long sentence about the separation of Obama that showed Trump is interested in the question. Holmes (2013, p.411) states 'speakers who use the standard variety are rated highly on scale of educational status; their speech indexes their high social status.' According to this, Trump also wants to show his social status toward mainstream society as a well-educated person because he tries to develop their utterance toward how his role in various aspects.

Furthermore, not only to express Trump's interest but also to show his power as president in the utterance that becomes the reason for flouting the maxim of quantity occurs. In some cases of flouting the maxim of quantity, Trump shows his interest in replying to his position as a president such as explaining the relationship with others' notions. In addition, Trump also tries to show the power of America toward the word such as the role to assist 


\section{Isma Farikha Latifatun Nuzulia}

China. All of this way is highly important for Trump to show his power as a government and public figure. He wants to deliver his role as a president and show how strong American in the world. This result also states by Edelman (1977) that the opinion of mainstream society can be generated by politician statements and action.

Additionally, the maxim of relation occurs as a further contribution at just below twenty percent of the total percentage. According to Grice (1976) to obey the cooperative principle of the maxim of relation, the speaker should 'be relevant' but in this case sometimes Trump did not enforce the role of this principle that can encourage to flout the maxim of relation. The example of the maxim of relation occurs that Trump provides information about building walls when the interviewer asks a question about the sense of supporters who voted for him. This case happens since Trump avoids sending clear answers to the issue and he gives irrelevant topics in this utterance. In this case, Trump explains the role of him in the building of the wall that the democrats do not want to establish it which is highly important for them. In other cases, when Trump flouts the maxim of relation, it is purposed to avoid giving a clear answer to the question.

Moreover, the flouting maxim of manner is the lowest quantity than other types at approximately 10 percent. Cutting (2002) states that the speakers should be brief and be orderly, and avoid obscurity and ambiguity in the utterance since disobeying these rules can flouting the maxim of manner. In this study, Trump flouts the maxim of manner twice which has different purposes. Firstly, Trump gives respond with the phrase 'Time will tell. Only time will tell' and this phrase is indicated as ambiguity since unclear information is performed. This type of maxim occurs to avoid a clear response since Trump does not know the clear information to be answered. Here, the application of implication is needed as Grundy (2000, p.73) states 'any meaning which is conveyed indirectly or through hints, and understood implicitly without ever being explicitly stated.' The hearer should find the hidden meaning of the utterance in order to understand the meaning which the speakers want to express. Thus, by giving ambiguity toward the question, Trump wants to share that he does not know the exact time to answer the question. Secondly, Trump repeatedly asks a question of a similar question that is asked by the interview, this means to ensure the question to him. In addition, flouting the maxim of quality does not find in this interview which means Trump rare uses irony, metaphor, meiosis, and hyperbole which can be indicated as flouting the maxim of quality.

The hidden message in Trump's utterance clearly requires the effort to find implicature by the hearer. Similarly, Sperber and Wilson, (2013 as cited by Taguchi) explain that indirectness in the utterance relates to the quantity of processing for comprehension. Comprehension can be a success if it is accessible but if not, the listeners require to build a bridge of structure that makes the comprehension more challenging. Also, the hearers need more effort to find an indirect idea if they cannot, the process of this is will not complete. Then, Sperber and Wilson (1995, p.177) define comprehension 'as a process of identifying the speaker's informative intention.' From this, to understand the implicature of Trump's utterance, TIME should have the appropriate skill of communication, especially when Trump flouts the maxim of relation and manner. 
Furthermore, all of the types of flouting maxim found in this study have a strong connection with the background of the speaker as the political figure. This occurs since the majority of the reason for the flouting maxim is to show his power as the politician. The utterance in the transcript of the interview also shows indirect meaning which is not directly expressing by the speaker. Here, Trump wants to explain his role as the president toward mainstream society and other countries. Additionally, he also desires to show that American is the strongest notion that plays a significant role in the world. Here, Trump tries to create a positive image as a politician and show his nationalism toward his notion. Similarly, Bourdieu (1991, p.127) states that political action 'aims to produce and impose representation (mental, verbal, visual, or theatrical) of the social world which may be capable of acting on agent's representation of it.' Thus, Trump also indirectly shows a representation of the power of American which has a role to assist many countries in the world.

Given is the previous study comparing the title 'The Cooperative Principle in Political Discourse: Flouting Gricean Maxim in Modern Standard Arabic Political Speech' by AlQaedri and Alduais (2019), it is found that flouting maxim occurs since the speaker wants to aware of certain topic, emphasize his ability as a president in a country and also want to create a positive impression or positive political image of him. This current research shows a similar result on how a positive image of politician figures their utterance. On the other hand, this previous study does not focus on the political background to be analyzed, but it prefers to how Grice's theory (1976) applies in a foreign language, Arabian language.

The second and third previous study entitled Furthermore, 'An Analysis of Flouting of Maxim Performed by Politician Guest in Mata Najwa Talkshow in the Episode of Adu Lantang Jelang Penetuan dan Babak Akhir Pilpers' by Aisya and Fitrawati (2019), and 'But We're Talking About Half-Beast Human: Conversational Implicature in the Television Talk Show with Anwar Ibrahim' by Larasati (2016) has a similar result to this recent study. The second previous study shows that the flouting maxim of quantity is the highest number which is indicated that the speaker tries to hold responsibility.. Then, the last previous research also shows a similar result that flouting the maxim of quantity is the largest number. Furthermore, the flout of maxim of that is done by the speaker as prime minister of Malaysia occurs because he wants to show his emotional bound for Indonesian immigrants who work in Malaysia and to protect him in the interview as self-defense.

Thus, this recent study complete the result of all the previous researches that the usage of flouting maxim in the politician language indicates to create a positive image as a president, regardless to show his social status, educational status, and the power of the government based on a relevant theory by Holmes (2013), Edelman (1977), Bourdieu (1991), and Partington \& Taylor, (2010). In addition, the finding in this current research also finds that the speaker shows how the strength of his country as a representative of America or to express his nationalism toward his notion.

\section{CONCLUSION}

This research aims to investigate the linguistic feature as a flouting maxim in the manuscript. After conducting the research, it is found that three types of flouting maxim which is the maxim of quantity, relation, and manner, occur during interview, but the other 


\section{Isma Farikha Latifatun Nuzulia}

one, flouting the maxim of quality, does not find in the transcript. Also, the flouting maxim of quantity is reported as the biggest quantity that means Trump frequently conveys more information than required. On the other hand, the number of flouting the maxim of relation and manner contributes as the less number, and it performs that sometimes Trump gives irrelevant respond to avoid giving the clear answer or to ensure the question asked.

Besides, after discussing the reason why Trump flouts maxim, it can be related to the background of Trump as the politician that he should create a positive image as the president. Besides, to create this good image Trump explains the important rule toward his notion and other countries in the world on how he builds good relationships with other countries. Also, Trump has a strong nationalism toward his notion which is showed when he explains that American is the strongest notion and helps other countries in the world.

After analyzing the finding in order to obtain sufficient data, the researcher noticed some deficiencies. The researcher does not find flouting the maxim of quality as the types of flouting maxim in this research. Thus, further research can use others object to be analyzed that have more complete data to be conducted. In addition, this research does not analyze the context of the utterance using the relevance theory, and it will be highly beneficial to analyze this kind in future research since context can assist the research to analyze the data.

\section{REFERENCES}

Aisya, N and Fitrawati. (2019). An Analysis of Flouting of Maxim Performed by Politician Guest in Mata Najwa Takshow in the Episode of Adu Lantang Jelang Penetuan Babak Akhir Pilpers. E-Journal of English Language and Literature. Volume 2 No 4. https://ejournal.unp.ac.id/index.php/jell.

Al-Qaedri, I and Alduais, A. (2019). The Cooperative Principle in Political Discourse: Flouting Gricean Maxim in Modern Standard Arabic Political Speech. Reseacrh Result

Theoretical and Applied Linguistic, 5 (3). DOI: 10.18413/2312-8912-2019-5-3-0-1.

Bourdieu, P. (1991). Language and Symbolic Power. Polity Press: United Kingdom.

Brown and Yule. (1988). Discourse Analysis. Cambridge: Cambridge University Press.

Chilton and Schäffner as cited by Patricia Dunmire (2012). Political Discourse Analysis:

Exploring the Language in Politics and the Politics of Language. Language and Linguistic Compass 6/11 (2020): 735-751. Doi: 10.1002/Inc3.365.

Creswell, J.W. (1997). Qualitative Inquiry and Research Design: Choosing among Five Tradition. London:Sage Publication, Inc.

Cruse, A. (2000). Meaning in Language An Introduction to Semantics and Pragmatics. New York: Oxford University Press.

Cruse, A. (2006). A Glossary of Semantic and Pragmatic. Edinburgh: Edinburgh University Press.

Cutting, J. (2002). Pragmatic and Discourse: A Resource Book for Students. New York: Longman.

Edelman, M.J. (1977) Political Language: Words that Succeed and Policies that Fail. New York: Academic Press. 
Fairclough, N. (1989). Language and Power. New York: Longman.

Grice, H.P.(1975). Logic and Conversation. In Petter and Jerry L.Morgan (Eds). Syntax and Semantics. Vol 3(41-58). New York.Academic Press, Inc.

Griffith, P. (2006). An Introduction to English Semantic and Pragmatic. Edinburgh: Edinburg University Press.

Grundy as cited by Nurul Chojimah. (2015). Utterances and their Meaning: as Introduction to Pragmatics. Lambert Academic Publishing: Latvia.

Grundy,P. (2000). Doing Pragmatics. Oxford: Oxford University Press.

Hall Edward T and Hall, Mildred. (1990). Understanding Cultural Differences: German, French and Americans. Intercultural Press.

Holmes, J. (2013). An Introduction to Sociolinguistic. Harlow. New York: Routledge.

Horn, L.R. and Ward, G. (2006). The Handbook of Pragmatic. UK: Backwell Publishing.

Kroeger, R,P. (2018). Analyzing Meaning: An Introduction to Sementic and Pragmatics (Texbooks in Language Science 5). Berlin: Language Science Press.

Larasati, A. (2016). But We're Talking About Half-Beast Human: Conversational Implicature in ta Television Talk Show with Anwar Ibrahim. Jurnal Bahasa, Sastra dan Budaya.Volume 12 Nomor 1. DOI:10.33633/lite.v12i1.1094.

Leech,N. (1983). Principle of Pragmatic. New York: Longman.

Levinson, C. (1983). Pragmatic. Cambridge: Cambridge University Press.

Mey, J,L. (2001). Pragmatics. An Introduction (2nd Ed). Oxford and New York: Routledge.

Oxford Advanced Learner's Dictionaries. (2005). Oxford: Oxford University Press.

Partington, A, Charlotte, T. (2010). Persuasion in Politics a Textbook. Milano: LED Edizioni Universitarie.

Spencer-Oatey, H and Zegarac V In Norbert Schmitt. (2002). Applied Linguistic. Hodder Education: London.

Sperber ,D., and Wilson, D. (1995) Relevance: Communicationand Cognition (2nd ed). Cambridge: Cambridge University Press.

Taguchi, N. (2013). Implicature. In P.Robinson (ed), Encyclopediaof SLA (p.296-298). Routledge.

Thomas, J.(1995). Meaning in Interaction: An Introduction to Pragmatic. New York: Routledge.

Wareing, S. (2004) 'What is Languae and What does it Do?', in Thomas, L (ed), Language, Society and Power. New York: Routledge.

Whitehorn as cited by Griffith, P. (2006). An Introduction to English Semantic and Pragmatic. Edinburgh: Edinburg University Press.

Yule, George. (1996). Pragmatics. Oxford University Press: New York.

Yule, George. (2010). The Study of Language. Cambridge University Press: Cambridge. 